\title{
19. GEOCHEMICAL STUDY OF THE CRETACEOUS-TERTIARY BOUNDARY REGION AT HOLE 752B
}

\author{
Helen V. Michel, ${ }^{2}$ Frank Asaro, ${ }^{2}$ and Walter Alvarez ${ }^{3}$
}

\begin{abstract}
Following neutron activation, a study was made with the Iridium Coincidence Spectrometer (ICS) of the abundance profile of iridium in the Cretaceous-Tertiary boundary region of cores from Hole 752B taken from the Indian Ocean west of Australia. The ICS was modified to measure 13 other elements simultaneously with the Ir determination, and data are included for $\mathrm{Co}, \mathrm{Cr}, \mathrm{Cs}, \mathrm{Fe}$, $\mathrm{Hf}$, and Se. The K-T region was sampled continuously in $1 \mathrm{~cm}$ increments from $8 \mathrm{~cm}$ below to $22 \mathrm{~cm}$ above the boundary, and an additional 30 spot samples were taken in the region from $10 \mathrm{~m}$ below to $6.7 \mathrm{~m}$ above.

A large Ir anomaly of 3800 parts per trillion (ppt) over a background of $22 \mathrm{ppt}$ was found in interval 121-752B-11R-3, 91-93 $\mathrm{cm}$. This interval overlaps the extinction level of globotruncanids determined by the Shipboard Scientific Party. After correcting for the estimated clay content, no Ir over the background was found in the region from $22 \mathrm{~cm}$ to $10 \mathrm{~m}$ below the main Ir peak. Iridium above background levels, however, was observed in all of the remaining samples up to $1 \mathrm{~m}$ above the main Ir peak. Between 2 and $5.7 \mathrm{~m}$ above the main Ir peak, the Ir level averaged $59 \mathrm{ppt}$ and is attributed to basaltic volcanism. Another large Ir anomaly of 1500 ppt was found in a spot sample from interval 121-752B-11R-3, 13-14 cm, and its tails extend from at least $10 \mathrm{~cm}$ below to at least $20 \mathrm{~cm}$ above the anomaly. The stratigraphic extent of this second anomaly parallels that of reworked Cretaceous nannofossils determined by the Shipboard Scientific Party, and the anomaly is attributed to reworking of K-T boundary Ir from another location.

By analogy with many other sections where the K-T Ir anomaly has been found, we consider the main Ir anomaly which peaks at interval 121-752B-11R-3, 91-93 cm, to be debris from the impact of a large asteroid or comet. A thin clay-enriched layer overlapping the main Ir peak, however, may have originated in part from basaltic volcanism triggered by the impact and in part from a decrease in biogenic productivity. Overall biogenic productivity recovered within $3 \mathrm{~cm}$ of the position of maximum Ir abundance.
\end{abstract}

\section{INTRODUCTION}

In 1980 it was suggested that the impact of a $10 \mathrm{~km}$ asteroid on the Earth 65 million years ago was responsible for large Ir enrichments found in K-T boundary clays near Gubbio in Italy, Stevns Klint in Denmark, and Woodside Creek in New Zealand (Alvarez et al., 1980). It was also suggested that debris from the impact was responsible for the Cretaceous-Tertiary (K-T) boundary clay and the K-T mass extinction. Since then there has been considerable confirming evidence that greatly enhanced Ir abundances occur world-wide in K-T boundary sediments wherever the sedimentation is continuous, that an asteroid or comet impact did occur at the time of the Ir deposition, and that the impact was synchronous with many extinctions of taxa (Alvarez et al., 1990; Alvarez and Asaro, 1990).

There have been suggestions that volcanic activity could have distributed the Ir world-wide (Officer et al., 1987, Hallam, 1987, Courtillot, 1990), but the close agreement of platinum-group-element ratios with meteorite values for some $\mathrm{K}-\mathrm{T}$ boundary sections (Ganapathy, 1980; Kastner et al., 1984), the discovery of shocked quartz with multiple intersecting lamellae in many K-T boundary sections (Bohor et al., 1984; Izett, 1987), and the difficulty of effecting a world-wide distribution by volcanic means makes the volcanic option seem unlikely to us.

The K-T boundary clay, however, has been found in some sections to be principally detrital in origin, e.g., the Bottaccione Gorge section near Gubbio (Kastner, 1982; Rampino and Reynolds, 1983; Johnson and Reynolds, 1986). It was suggested that

\footnotetext{
'Weissel, J., Peirce, J., Taylor, E., Alt, J., et al., 1991. Proc. ODP, Sci. Results, 121: College Station, TX (Ocean Drilling Program).

${ }^{2}$ Applied Science Division, Lawrence Berkeley Laboratory, University of California, Berkeley, CA 94720 , U.S.A.

${ }^{3}$ Department of Geology and Geophysics, University of California, Berkeley, CA 94720 , U.S.A.
}

the Stevns Klint boundary clay resulted from alteration of microtektites which were fallout from an impact event (Kastner et al., 1984) but it was also suggested that it was locally derived (Schmitz, 1988) or due to basaltic volcanism (Elliot et al., 1989). In another example, clay in the K-T boundary region of DSDP 690C commenced with the deposition of the main Ir peak but continued for a meter whereas the Ir was sharply peaked. The clay, including that deposited with the Ir peak, was predominantly detrital (Michel et al., 1990).

It was suggested, however, that the impact of a $10 \mathrm{~km}$ bolide should cause volcanism to occur somewhere (Lipman in Kerr, 1988). The preliminary shipboard studies of Hole 752B indicated there were deposits of altered volcanic basalts near the K-T boundary. The present study was undertaken to determine if the $\mathrm{K}-\mathrm{T}$ Ir anomaly was present in Hole $752 \mathrm{~B}$ and, if so, whether volcanism might be associated with its deposition.

\section{LITHOLOGY}

The core containing the K-T boundary, 121-752B-11R, had been fractured in the drilling process and about one-half was missing. Of the $4.6 \mathrm{~m}$ not recovered, about $0.9 \mathrm{~m}$ was lost from the region near the K-T boundary (Shipboard Scientific Party, 1988a). Figure 1 is a photograph of the working half of Core 121-752B-11R from which our samples were taken. The K-T region is best described by quoting from the Cretaceous/Tertiary boundary summary of the Initial Reports (Shipboard Scientific Party, 1988a) "Light gray, mottled, and faintly laminated chalks of latest Maestrichtian age record open-ocean deposition at high mass-accumulation rates of 4 to $4.7 \mathrm{~g} / \mathrm{cm}^{2} / 1000 \mathrm{yr}$, implying continuing high productivity. The chalks terminate at a biscuit boundary, above which is a large burrow structure capped by an ash layer, which in turn is overlaid by a chalk exhibiting soft-sediment deformation or slump structures. Above the next biscuit boundary is $8 \mathrm{~cm}$ of gray chert and porcellanite in several pebbles. Above the chert pebbles, a light gray chalk layer grades upward 
into another ashy unit recovered in two biscuits. Above the ash layer are $23 \mathrm{~cm}$ of gray chalk in six biscuits. There are a total of 10 biscuit boundaries within the one core interval that contains the boundary." Because the position of the biscuits can change slightly whenever the core is moved, the core fragments from which our samples were taken may have shifted by about 1 or 2 $\mathrm{cm}$ from the positions indicated in Figure 1.

\section{SAMPLE PREPARATION}

The K-T region was sampled by the Ocean Drilling Program repository staff in $1 \mathrm{~cm}$ continuous increments from $8 \mathrm{~cm}$ below to $22 \mathrm{~cm}$ above a clay-enriched layer where the Shipboard Scientific Party had detected extinctions. Below this region, samples were taken every $5 \mathrm{~cm}$ for $35 \mathrm{~cm}$ and then every $10 \mathrm{~cm}$ for $30 \mathrm{~cm}$ where Core 121-752B-11R terminated. Four more Cretaceous background samples were taken in Core 121-752B-12R spaced by about $1 \mathrm{~m}$ intervals. Above the region of continuous sampling, samples were taken every $5 \mathrm{~cm}$ for $25 \mathrm{~cm}$, every $10 \mathrm{~cm}$ for $50 \mathrm{~cm}$ and every meter for about $4 \mathrm{~m}$.

Each sample was ground with an agate mortar and pestle. Twenty-five to $100 \mathrm{mg}$ of each sample were weighed and then encapsulated in a $0.020 \mathrm{~cm}$ thick $99.9995 \%$ pure Al foil prior to irradiation. Typically a $100 \mathrm{mg}$ sample is used for calcareous samples with an estimated clay content of less than $15 \%$, and 50 and $25 \mathrm{mg}$ samples are used, respectively, for estimated clay contents of $15-30 \%$ and greater than $30 \%$. The Al capsules are sealed in quartz tubes in groups of 50 and irradiated in the University of Missouri Triga reactor for $144 \mathrm{hr}$ at a flux of 2.5 $\times 10^{13}$ neutrons $/ \mathrm{s}-\mathrm{cm}^{2}$.

\section{MEASUREMENT PROCEDURES}

All 60 samples were measured with the ICS (Alvarez et al., 1988, Asaro et al., 1987) at times ranging from 6 to 21 weeks after the irradiation. The ICS has two Ge detectors with faces $20 \mathrm{~mm}$ apart which are shielded by twin tanks of scintillator-doped mineral oil surrounding them. Gamma rays from a sample inserted between the $\mathrm{Ge}$ detectors interact with the detectors, and coincidences between the 316.5 and $468.1 \mathrm{keV}$ gamma rays of ${ }^{192} \mathrm{Ir}$ are monitored. High-energy coincident gamma rays from other nuclides, which can scatter in the Ge detectors and emulate ${ }^{192} \mathrm{Ir}$ radiations, are rejected when the scattered components are detected by the shield. A more detailed discussion can be found in Michel et al. (1990).

The ICS electronic system (excluding the amplifiers and preamplifiers) has been completely revised and modified to simultaneously measure 13 elements in addition to the Ir. Measurements can now be made by four different methods: (1) singles measurements with one $\mathrm{Ge}$ detector and rejection of radiations which have a coincidence with the shield, (2) the same measurement as 1 but without rejection, (3) coincidence measurements between two gamma rays with two Ge detectors and rejection of counts which also have a coincidence with the shield, and (4) the same measurement as 3 but without rejection. In method 1 the rejection of pulses which have a coincidence with the shield lowers the background underneath the gamma rays and permits better sensitivity and precision. If a nuclide has significant amounts of radiation which are coincident with the gamma ray triggering the Ge detector, however, these radiations will trigger the shield and lower the efficiency of detection for the gamma ray of interest. Method 2, which ignores the shield, is better for such nuclides. Method 3 works best for those nuclides which have gamma rays difficult to detect in the singles measurements and which are in abundant coincidence with each other, but not with any other gamma rays. Method 4 may be best for those nuclides whose most intense gamma rays have two or more other gamma rays in coincidence. It has not been used yet.

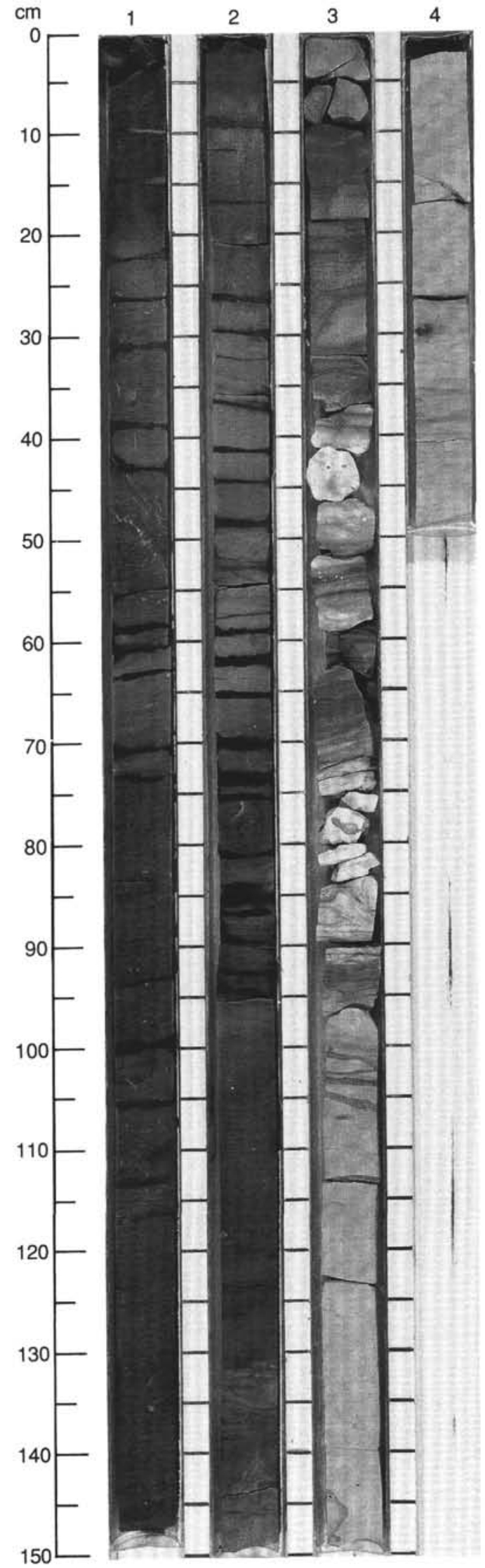

Figure 1. Photograph of the working half of Core 121-752B$11 \mathrm{R}$ prior to sampling. 
Among the elements reported, $\mathrm{Fe}, \mathrm{Ta}$, and $\mathrm{Cr}$ are measured by the first method, Co, Hf, and Cs by the second method, and Ir and Se by the third method. All elements measured in the singles mode except $\mathrm{Cr}$ were measured by two different radiations. The measurement of Se at the $25 \mathrm{ppb}$ level by the ICS is about 5000 times faster than we could have done previously with our conventional equipment (if it had been worthwhile to spend the counting time).

Measurements on $\mathrm{Ag}, \mathrm{Eu}, \mathrm{Th}, \mathrm{Ce}$, and $\mathrm{Sb}$ were made but are not included here because further tests of their reliability are necessary before publishing the data. Sc data were also taken but are not included because the corrections due to the Sc contamination in the high purity Al have not yet been made.

Precisions in measurement (i.e., counting errors) for $\mathrm{Fe}$ and $\mathrm{Co}$ abundances are better than $1 \%$, and those of $\mathrm{Cr}$ and $\mathrm{Hf}$ are better than $2 \%$ and $3 \%$, respectively. The counting errors for Ta, Cs, and Se are more variable and average about $4 \%, 4 \%$, and $3 \%$ respectively. The $\mathrm{Cr}$ abundances are not corrected for the iron content of the samples (which produce ${ }^{51} \mathrm{Cr}$ radiations during neutron irradiation) and are therefore too high. The error in ppm is estimated at about one-half of the iron content expressed in percent. The accuracy of measurement includes not only the precision of measurement but also the uncertainties in the abundances of the elements in the standards. Dino-1 (Alvarez et al., 1982) is used for Se and Ir calibration and Standard Pottery (Perlman et al., 1969, 1971; Alvarez et al., 1982) is used for all of the other elements. The uncertainties in the abundances of the elements in the standards expressed as percent (in parentheses) are: $\operatorname{Ir}(2.0)$, $\mathrm{Se}(20), \mathrm{Ta}(2.8), \mathrm{Co}(1.1), \mathrm{Fe}(1.2), \mathrm{Cs}(6.6), \mathrm{Hf}(7.1)$, and $\mathrm{Cr}(3.8)$. The Se uncertainty is so high because a flux monitor was used for its measurement in DINO-1. Because the system is very new and has not been thoroughly tested for a long period of time, there may be errors of which we are not aware.

\section{CONTAMINATION}

Because hard, particulate contamination of samples or their $\mathrm{Al}$ capsules with Ir is a distinct possibility in our laboratory, samples with unusual Ir abundances are split into two and recounted. Two samples from a large Ir spike at interval 121-752B-11R-3, 90-91 $\mathrm{cm}$, and $91-92 \mathrm{~cm}$, one sample from below the spike at interval 121-752B-11R-3, 104-105 cm, and one sample from above the spike at interval 121-752B-11R-3, 13-14 cm, were split and recounted. All samples had the same Ir abundance in the split as in the parent sample within counting errors and were judged to be not contaminated. A sample from interval 121-752B-11R-3, 41$42 \mathrm{~cm}$, which was one of several with unusually high amounts of $\mathrm{Ta}, \mathrm{Hf}$, and Th, was split, recounted, and found to have the same abundances of these elements in the parent and split samples within counting errors.

\section{RESULTS AND INTERPRETATION}

\section{Data}

Table 1 shows the abundance data for Ir and seven other elements. The errors shown on the Ir measurements, where symmetrical, are $1 \sigma$ Gaussian values and Poisson values otherwise. The Poisson upper errors were chosen such that samples whose true abundances were equal to the observed values plus errors would indicate abundances below the observed values less than $16 \%$ of the time. The Poisson lower errors were chosen analogously. The Poisson errors slowly converge to Gaussian values with increasing numbers of counts, and the computer program automatically switches to Gaussian statistics when the gross counts in a peak reach 31 . The errors for the other elements were discussed in "Contamination" above. Figure 2 shows the Ir abundances with errors for the 60 samples measured in this work.
Figure 3 shows the Ir profile in more detail around the peak regions.

The altered ash layers reported for Hole 752B and other nearby sites of Leg 121 are dominantly basaltic (Shipboard Scientific Party, 1988b). The element Cs provides an unusual opportunity to study the content of clay from the continents because its abundance is unusually low in many basalts. Figure 4 shows the ratios of Ir to Cs abundances near the Ir peaks.

Because altered basalts are rich in iron, the $\mathrm{Fe} / \mathrm{Cs}$ ratio can serve as an indicator of basaltic volcanism even in the presence of detrital clay. Figure 5 shows the ratios of $\mathrm{Fe}$ to $\mathrm{Cs}$ abundances for all the samples, and Figure 6 shows the ratios in more detail near the Ir peaks. Co and Fe are chemically related, and differences in their ratios can reflect different sources of the sediment. Figure 7 shows the $\mathrm{Co} / \mathrm{Fe}$ ratios for all of the samples.

\section{Background Regions}

From the lowest Maestrichtian sample measured at interval 121-752B-12r-2, 122-123 cm, to interval 121-752B-11R-3, 114$115 \mathrm{~cm}$, the average Ir abundance is $21.5 \mathrm{ppt}$. This background should have components due to cosmic dust, basaltic volcanism, and clay originating from windblown or river-carried continental debris. These are not the only sources which can inject background $\mathrm{Ir}$ into sediments, just the ones we consider most likely. If we look at the samples with lowest $\mathrm{Fe}$ content to reduce the basaltic volcanism component (the six samples from interval 121-752B-11R-3, 119-120 cm, to interval 121-752B-11R-4, 14$15 \mathrm{~cm}$ ), the Ir average background is just $14.1 \pm 2.4 \mathrm{ppt}$. From the Kyte and Wasson (1986) estimate of the extraterrestrial Ir content of deep-sea red clays $\left(0.009 \pm 0.003 \mathrm{ng} \mathrm{Ir} / \mathrm{cm}^{2} / \mathrm{ka}\right)$ and the late Maestrichtian sedimentation rate reported by the Shipboard Scientific Party $\left(4.0-4.7 \mathrm{~g} / \mathrm{cm}^{2} / \mathrm{ka}\right)$, the cosmic dust component should be about $2 \mathrm{ppt}$. An estimate can be made of the river-carried component from a study of the Ir and $\mathrm{Fe}$ in Mississippi River suspended matter (Fenner and Presley, 1984). Their average Ir/Fe ratio was $14 \times 10^{-10}$. With that value and the average $\mathrm{Fe}$ abundance in our low background region, $0.43 \%$, the calculated Ir component would be 6 ppt. The remaining 6 ppt Ir in the background could be due to biogenic or hydrogenic causes. Mn deposits, for example, can concentrate Ir out of their environment, and some phosphate and some organic deposits have been found to do the same. Crocket and Kuo (1979) give a discussion of various sources of Ir background. The remaining Ir could also be due to larger values of the lithogenic component discussed above because the Ir background near Gubbio, Italy, in sediments with comparable Fe, is 12 ppt (Alvarez et al., 1990).

The low average $\mathrm{Fe}$ content, $0.431 \%$, and the low standard deviation in the ratio of $\mathrm{Fe} / \mathrm{Cs}$ abundances, $5.2 \%$, suggest that any component of episodic volcanism in the background is small, and a maximum can be estimated. The Ir abundance in Sample 121$752 \mathrm{~B}-11 \mathrm{R}-1,93-94 \mathrm{~cm}$, is $44 \pm 21 \mathrm{ppt}$. As this sample comes from a location in the core described by the Shipboard Scientific Party as a volcanic ash (which is supported by the iron content of $7.6 \%$ and high $\mathrm{Fe} / \mathrm{Cs}$ ratio of 24 , in the units given in Table 1), the 44 $\pm 21 \mathrm{ppt}$ may be a reasonable estimate of the Ir in the volcanic basalts in this region. If we normalize the iron content of this sample to the average in the background region discussed above $(0.431 \%)$, then the expected $\mathrm{Ir}$ abundance would be a maximum of $2.5 \pm 1.2 \mathrm{ppt}$ if all of the iron abundance is due to basaltic volcanism.

As the $\mathrm{Fe} / \mathrm{Cs}$ ratio in the background region discussed above averages 1.84 and that in the sample from interval 121-752B$11 \mathrm{R}-1,93-94 \mathrm{~cm}$, which we believe is predominantly an altered volcanic basalt, is 24 , the $\mathrm{Cs}$ in the background region is predominantly due to deposits other than volcanic ash. In contrast, sam- 
Table 1. Abundance of Ir and other elements from Hole 752B using the Iridium Coincidence Spectrometer.

\begin{tabular}{|c|c|c|c|c|c|c|c|c|c|c|c|}
\hline $\begin{array}{l}\text { Core, section, } \\
\text { interval }(\mathrm{cm})\end{array}$ & $\begin{array}{l}\text { Depth } \\
\text { (mbsf) }\end{array}$ & $\begin{array}{c}\text { Ir } \\
\text { (ppt) }\end{array}$ & + err & - err & $\begin{array}{l}\text { Co } \\
\text { (ppm) }\end{array}$ & $\begin{array}{l}\mathrm{Fe} \\
(\%)\end{array}$ & $\underset{(\mathrm{ppm})}{\mathrm{Cs}}$ & $\begin{array}{c}\mathrm{Hf} \\
(\mathrm{ppm})\end{array}$ & $\underset{(\mathrm{ppm})}{\mathrm{Cr}}$ & $\begin{array}{c}\mathrm{Se} \\
(\mathrm{ppb})\end{array}$ & $\begin{array}{c}\text { Ta } \\
\text { (ppm) }\end{array}$ \\
\hline $10 R-5,93-94$ & 352.03 & 14 & 10 & 8 & 3.01 & 0.826 & 0.193 & 0.70 & 4.6 & 58 & 0.128 \\
\hline 10R-6, 43-44 & 353.03 & 68 & 10 & 10 & 19.39 & 4.335 & 0.403 & 1.62 & 56.0 & 247 & 0.244 \\
\hline $11 \mathrm{R}-1,93-94$ & 355.73 & 44 & 21 & 21 & 30.18 & 7.606 & 0.311 & 3.09 & 24.7 & 809 & 0.464 \\
\hline $11 R-2,44-45$ & 356.74 & 65 & 10 & 10 & 16.61 & 4.403 & 0.592 & 2.05 & 26.0 & 304 & 0.361 \\
\hline $11 R-2,143-144$ & 357.73 & 320 & 37 & 37 & 11.03 & 2.814 & 0.339 & 3.34 & 28.5 & 316 & 0.876 \\
\hline $11 R-3,3-4$ & 357.83 & 151 & 19 & 19 & 5.42 & 1.370 & 0.164 & 1.65 & 14.2 & 157 & 0.428 \\
\hline $11 \mathrm{R}-3,13-14$ & 357.93 & 1487 & 97 & 97 & 29.14 & 7.003 & 0.663 & 2.70 & 48.6 & 406 & 0.559 \\
\hline $11 R-3,22-23$ & 358.02 & 257 & 19 & 19 & 22.28 & 6.163 & 0.331 & 2.91 & 41.9 & 475 & 0.713 \\
\hline $11 \mathrm{R}-3,33-34$ & 358.13 & 110 & 20 & 20 & 8.54 & 2.699 & 0.390 & 3.32 & 16.7 & 281 & 0.956 \\
\hline $11 R-3,41-42$ & 358.21 & 41 & 7 & 7 & 4.11 & 0.967 & 0.115 & 3.19 & 3.8 & 141 & 1.135 \\
\hline $11 R-3,47-48$ & 358.27 & 51 & 8 & 8 & 4.03 & 0.643 & 0.109 & 0.74 & 6.0 & 157 & 0.204 \\
\hline $11 \mathrm{R}-3,54-55$ & 358.34 & 116 & 21 & 21 & 4.93 & 1.574 & 0.192 & 0.88 & 13.8 & 547 & 0.188 \\
\hline $11 R-3,58-59$ & 358.38 & 79 & 12 & 12 & 4.55 & 1.292 & 0.139 & 0.77 & 14.8 & 514 & 0.130 \\
\hline $11 R-3,64-65$ & 358.44 & 131 & 23 & 23 & 19.71 & 4.869 & 0.283 & 1.65 & 21.3 & 746 & 0.267 \\
\hline $11 R-3,68-69$ & 358.48 & 194 & 37 & 37 & 18.93 & 3.866 & 0.220 & 1.76 & 42.2 & 1872 & 0.348 \\
\hline $11 \mathrm{R}-3,69-70$ & 358.49 & 249 & 42 & 42 & 17.16 & 3.946 & 0.244 & 1.67 & 41.0 & 1812 & 0.324 \\
\hline $11 \mathrm{R}-3,70-71$ & 358.50 & 189 & 41 & 41 & 17.37 & 3.349 & 0.214 & 1.79 & 45.4 & 2047 & 0.361 \\
\hline $11 R-3,71-72$ & 358.51 & 355 & 60 & 60 & 43.25 & 3.014 & 0.220 & 1.97 & 44.2 & 9136 & 0.396 \\
\hline $11 R-3,72-73$ & 358.52 & 308 & 42 & 42 & 18.72 & 1.659 & 0.166 & 1.25 & 30.5 & 1724 & 0.265 \\
\hline $11 R-3,73-74$ & 358.53 & 436 & 54 & 54 & 54.06 & 2.191 & 0.234 & 1.55 & 46.6 & 3563 & 0.281 \\
\hline $11 \mathrm{R}-3,74-75$ & 358.54 & 126 & 20 & 20 & 6.32 & 0.400 & 0.079 & 0.28 & 5.5 & 697 & 0.054 \\
\hline $11 R-3,75-76$ & 358.55 & 191 & 27 & 27 & 8.51 & 0.602 & 0.119 & 0.43 & 11.0 & 1341 & 0.064 \\
\hline $11 R-3,76-77$ & 358.56 & 123 & 17 & 17 & 4.26 & 0.232 & 0.050 & 0.19 & 3.7 & 690 & 0.038 \\
\hline $11 R-3,77-78$ & 358.57 & 84 & 14 & 14 & 2.51 & 0.162 & 0.046 & 0.17 & 3.4 & 335 & 0.033 \\
\hline $11 R-3,78-79$ & 358.58 & 69 & 12 & 12 & 1.85 & 0.147 & 0.049 & 0.17 & 2.7 & 273 & 0.030 \\
\hline $11 R-3,79-80$ & 358.59 & 105 & 15 & 15 & 3.15 & 0.150 & 0.053 & 0.18 & 3.5 & 395 & 0.036 \\
\hline $11 R-3,80-81$ & 358.60 & 392 & 22 & 22 & 7.09 & 0.323 & 0.113 & 0.32 & 6.5 & 799 & 0.080 \\
\hline $11 R-3,81-82$ & 358.61 & 320 & 27 & 27 & 2.74 & 0.208 & 0.073 & 0.26 & 4.5 & 460 & 0.061 \\
\hline $11 \mathrm{R}-3,82-83$ & 358.62 & 587 & 41 & 41 & 8.65 & 0.451 & 0.152 & 0.49 & 9.1 & 714 & 0.120 \\
\hline $11 \mathrm{R}-3,83-84$ & 358.63 & 599 & 40 & 40 & 8.20 & 0.405 & 0.134 & 0.47 & 8.2 & 693 & 0.115 \\
\hline $11 \mathrm{R}-3,84-85$ & 358.64 & 581 & 41 & 41 & 11.28 & 0.435 & 0.148 & 0.46 & 8.3 & 813 & 0.122 \\
\hline $11 \mathrm{R}-3,85-86$ & 358.65 & 290 & 42 & 42 & 5.97 & 0.251 & 0.071 & 0.25 & 3.7 & 500 & 0.056 \\
\hline $11 \mathrm{R}-3,86-87$ & 358.66 & 502 & 26 & 26 & 4.92 & 0.462 & 0.117 & 0.42 & 6.9 & 536 & 0.107 \\
\hline $11 R-3,87-88$ & 358.67 & 757 & 70 & 70 & 9.38 & 0.741 & 0.202 & 0.73 & 12.5 & 770 & 0.190 \\
\hline $11 R-3,88-89$ & 358.68 & 952 & 96 & 96 & 16.32 & 1.121 & 0.207 & 1.01 & 16.4 & 913 & 0.239 \\
\hline $11 R-3,89-90$ & 358.69 & 1926 & 211 & 211 & 31.06 & 2.563 & 0.307 & 1.88 & 28.0 & 1394 & 0.405 \\
\hline $11 R-3,90-91$ & 358.70 & 2785 & 174 & 174 & 53.30 & 4.695 & 0.505 & 3.07 & 43.8 & 1833 & 0.795 \\
\hline $11 \mathrm{R}-3,91-92$ & 358.71 & 3813 & 118 & 118 & 59.03 & 3.998 & 0.446 & 3.13 & 44.6 & 2398 & 0.816 \\
\hline $11 R-3,92-93$ & 358.72 & 3754 & 278 & 278 & 48.19 & 1.977 & 0.462 & 2.10 & 39.9 & 2203 & 0.527 \\
\hline $11 \mathrm{R}-3,93-94$ & 358.73 & 1398 & 137 & 137 & 13.59 & 1.158 & 0.340 & 1.03 & 16.2 & 775 & 0.266 \\
\hline $11 \mathrm{R}-3,94-95$ & 358.74 & 1220 & 125 & 125 & 14.13 & 1.077 & 0.282 & 1.08 & 15.2 & 1164 & 0.240 \\
\hline $11 \mathrm{R}-3,95-96$ & 358.75 & 89 & 21 & 18 & 2.59 & 0.632 & 0.263 & 0.45 & 5.2 & 122 & 0.084 \\
\hline $11 \mathrm{R}-3,96-97$ & 358.76 & 154 & 25 & 25 & 3.85 & 1.118 & 0.360 & 0.66 & 6.5 & 345 & 0.116 \\
\hline $11 R-3,97-98$ & 358.77 & 143 & 24 & 24 & 3.03 & 0.907 & 0.305 & 0.56 & 6.2 & 216 & 0.090 \\
\hline $11 \mathrm{R}-3,98-99$ & 358.78 & 106 & 10 & 10 & 2.91 & 1.096 & 0.333 & 0.56 & 5.9 & 127 & 0.105 \\
\hline $11 R-3,99-100$ & 358.79 & 98 & 12 & 12 & 2.19 & 0.633 & 0.241 & 0.43 & 4.9 & 95 & 0.085 \\
\hline $11 \mathrm{R}-3,104-105$ & 358.84 & 862 & 41 & 41 & 11.25 & 0.706 & 0.296 & 0.96 & 13.7 & 1859 & 0.243 \\
\hline $11 \mathrm{R}-3,109-110$ & 358.89 & 35 & 7 & 7 & 2.43 & 0.504 & 0.239 & 0.44 & 4.9 & 272 & 0.088 \\
\hline $11 R-3,114-115$ & 358.94 & 19 & 7 & 6 & 2.74 & 0.662 & 0.257 & 0.54 & 7.4 & 134 & 0.107 \\
\hline $11 \mathrm{R}-3,119-120$ & 358.99 & 12 & 3 & 3 & 2.09 & 0.437 & 0.235 & 0.47 & 4.8 & 114 & 0.092 \\
\hline $11 \mathrm{R}-3,124-125$ & 359.04 & 23 & 8 & 6 & 3.19 & 0.386 & 0.215 & 0.50 & 5.3 & 177 & 0.100 \\
\hline $11 R-3,134-135$ & 359.14 & 18 & 8 & 6 & 2.58 & 0.371 & 0.221 & 0.49 & 5.1 & 199 & 0.096 \\
\hline $11 R-3,144-145$ & 359.24 & 12 & 8 & 6 & 4.72 & 0.392 & 0.211 & 0.44 & 4.1 & 143 & 0.086 \\
\hline $11 R-4,4-5$ & 359.34 & 10 & 8 & 6 & 1.77 & 0.500 & 0.256 & 0.58 & 5.4 & 78 & 0.117 \\
\hline $11 R-4,14-15$ & 359.44 & 18 & 11 & 8 & 2.30 & 0.501 & 0.262 & 0.58 & 5.6 & 134 & 0.109 \\
\hline $11 \mathrm{R}-4,25-26$ & 359.55 & 33 & 14 & 11 & 5.03 & 0.790 & 0.256 & 0.88 & 5.5 & 256 & 0.155 \\
\hline $12 \mathrm{R}-1,24-25$ & 364.64 & 21 & 21 & 16 & 13.75 & 3.709 & 0.329 & 1.93 & 53.6 & 163 & 0.454 \\
\hline $12 R-1,111-112$ & 365.51 & 28 & 13 & 10 & 4.53 & 1.371 & 0.295 & 0.99 & 10.7 & 159 & 0.222 \\
\hline $12 \mathrm{R}-2,23-24$ & 366.13 & 52 & 23 & 18 & 10.17 & 3.014 & 0.324 & 0.97 & 27.4 & 353 & 0.148 \\
\hline $12 \mathrm{R}-2,122-123$ & 367.12 & 12 & 11 & 8 & 5.03 & 0.764 & 0.248 & 0.88 & 13.0 & 286 & 0.236 \\
\hline
\end{tabular}

ples from intervals $121-752 \mathrm{~B}-12 \mathrm{R}-1,24-25 \mathrm{~cm}$, and $121-752 \mathrm{~B}-$ $12 \mathrm{R}-2,23-24 \mathrm{~cm}$, have much smaller $\mathrm{Fe} / \mathrm{Cs}$ ratios (close to 10 ) and probably contain basaltic ash deposits.

$\mathrm{Cs}$ is a monovalent element and is thought to be mainly associated with aluminosilicates in sediments. The Cs abundance can then serve as a monitor of the deposition rate of windblown and river-carried debris from the continents. To the extent that this rate can be considered as constant, during changes in biogenic and volcanic debris deposition rates, the inverse of the Cs abundance (after correction for the mass of any episodic volcanic debris) can serve as a monitor of the overall deposition rate and, hence, the biogenic productivity. There have been problems with seawater alteration of $\mathrm{Cs}$ abundances in diagenesis of basalts (Basaltic Volcanism Study Project, 1981). In the measurements reported here, however, the $\mathrm{Cs}$ from the basalts is small enough that alteration is not a concern. The Cs contents of concern are those from clay transported from the continents, and Cs abundances have been found to be one of the reliable indicators for identifying clay origins (Perlman and Asaro, 1969).

\section{Main Ir Peak And Nannofossil Extinction Level}

The largest $\mathrm{Ir}$ peak is nearly centered between intervals 121 $752 \mathrm{~B}-11 \mathrm{R}-3,91-92 \mathrm{~cm}$, and $92-93 \mathrm{~cm}$. The extinction of globotruncanids was reported by the Shipboard Scientific Party in 


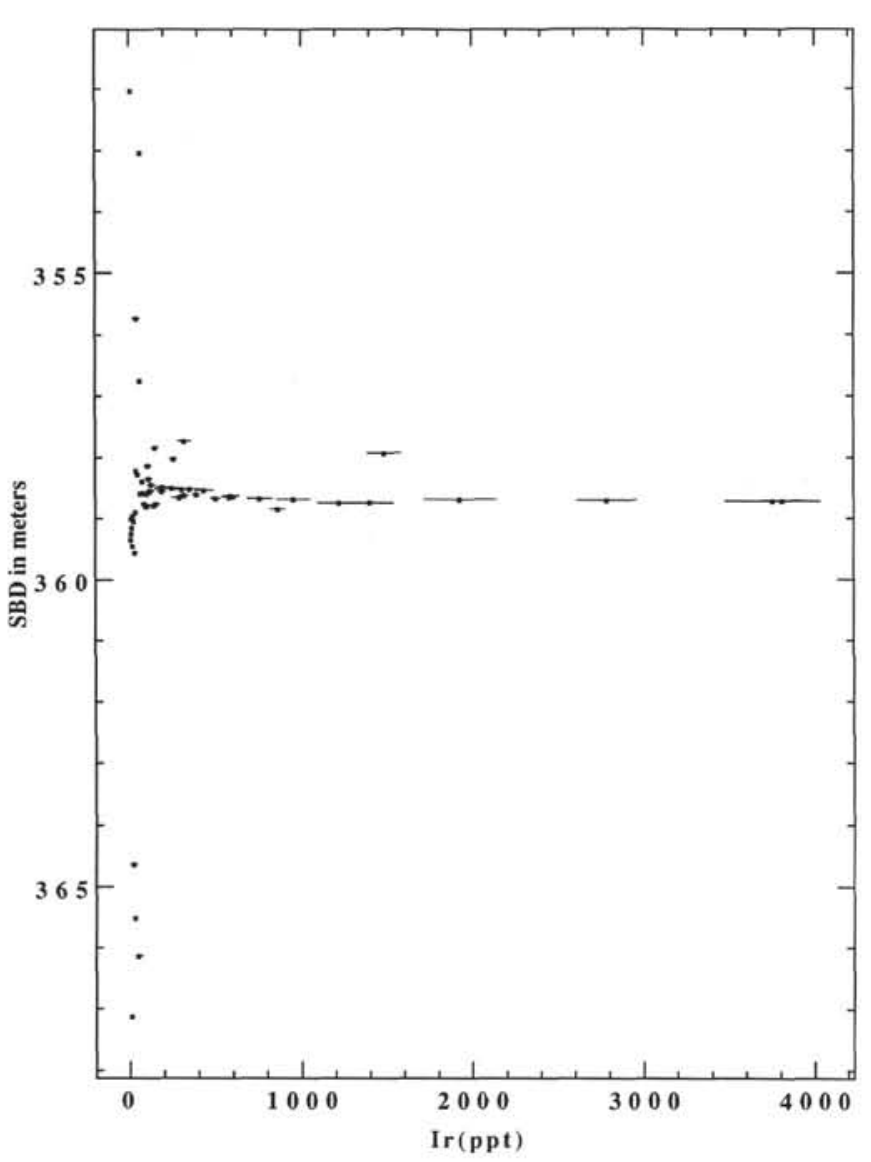

Figure 2. Iridium abundance profile vs. stratigraphic depth for all samples studied from Hole 752B.

their Figure 2 to be at interval 121-752B-11R-3, $95 \mathrm{~cm}$. In order to determine how close the Ir peak is to the extinction level, we have to evaluate how the core may have shifted between the two measurements. The Shipboard Scientific Party found the extinction level to be $1 \mathrm{~cm}$ below the base of a $2 \mathrm{~cm}$ thick dark layer. This latter layer probably corresponds to our $2 \mathrm{~cm}$ of maximum Fe abundance whose base is at interval 121-752B-11R-3, $92 \mathrm{~cm}$, and the extinction level in our samples should therefore be $1 \mathrm{~cm}$ below that at $93 \mathrm{~cm}$. Thus, the extinction level and the base of the most intense part of the Ir peak agree as close as we can measure. There is a $2 \mathrm{~cm}$ shift between the Shipboard Scientific Party's Figure 2 (and also our Fig. 1) and our measurement regime in the given position of Section 121-752B-11R-3. Because the relative positions of fragments in the section can shift with respect to each other when the section is moved, the $2 \mathrm{~cm}$ shift is probably not constant. Unless explicitly stated otherwise, core positions refer to our measurement regime.

The total Ir over background deposited in the interval in Section $121-752 \mathrm{~B}-11 \mathrm{R}-3$ between 68 and $100 \mathrm{~cm}$ is $23,146 \mathrm{ppt}-$ $\mathrm{cm}$ (this calculation includes the sample at interval 121-752B$11 \mathrm{R}-3,104-105 \mathrm{~cm}$, and assumes the sample actually belongs next to the main Ir peak). With an assumed density of $2.5 \mathrm{~g}$ rock $/ \mathrm{cm}^{3}$, the total Ir surface density is roughly $58 \times 10^{-9} \mathrm{~g} \mathrm{Ir} / \mathrm{cm}^{2}$, intermediate among marine anomalies. For comparison, the Ir anomaly near Gubbio, Italy, with $23 \times 10^{-9} \mathrm{~g} \mathrm{Ir} / \mathrm{cm}^{2}$ (Alvarez et al., 1990), is among the lowest while one in the USSR with 580 $\times 10^{-9} \mathrm{~g} \mathrm{Ir} / \mathrm{cm}^{2}$ (Nazarov et al, 1987) is the highest.

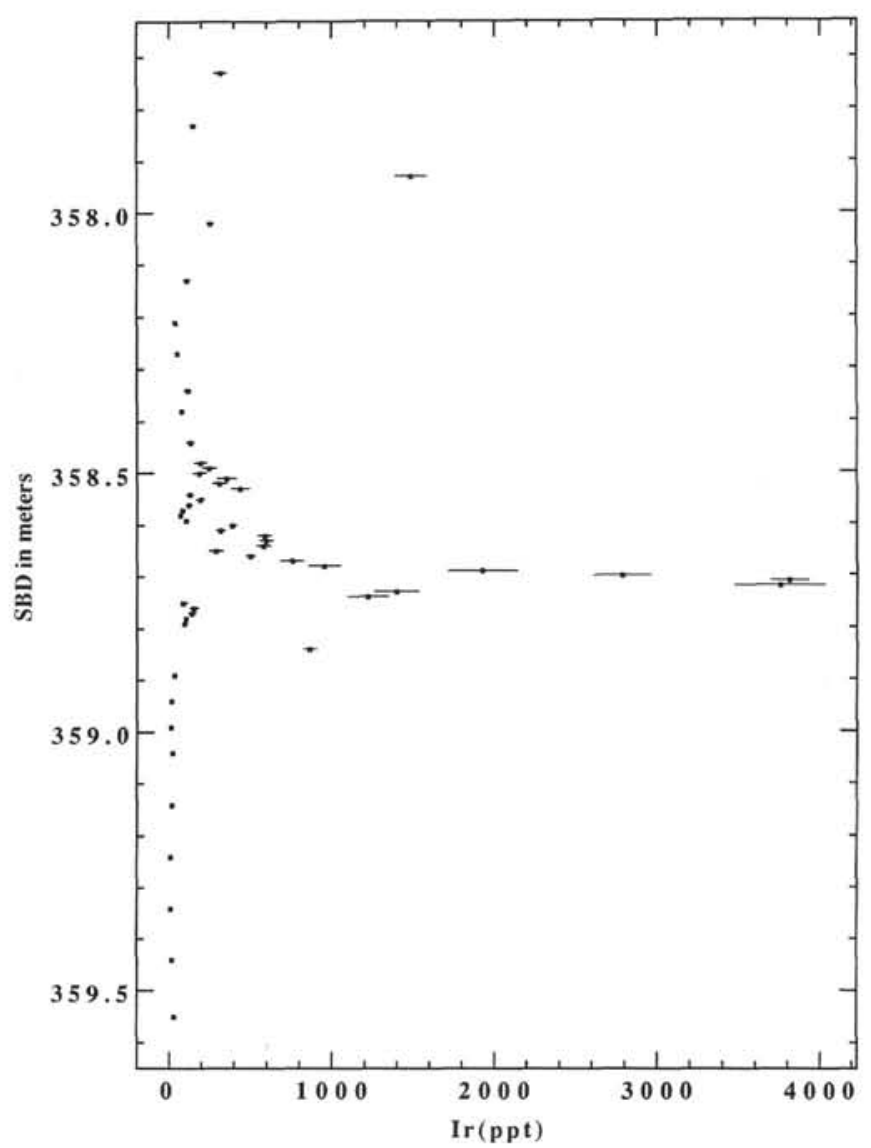

Figure 3. Detailed iridium abundance profile vs. stratigraphic depth for samples in the peak regions.

\section{Origin of the K-T Boundary Clay}

The best choice of assignments for the clay in the region of the main Ir peak is most likely between an impact component; such as has been reported for Stevns Klint (but questioned by Schmitz and by Elliot et al.), DSDP Hole 465A, and Woodside Creek; a basaltic ash, such as reported for other regions of this core; or a detrital component caused by slowing down of the $\mathrm{CaCO}_{3}$ deposition rate, such as found in ODP Hole $690 \mathrm{C}$. In the three sections mentioned above, the striking feature is the very close agreement among them for the anomalous amounts of many elements. For example, the average difference between Stevns Klint and DSDP Hole 465 A K-T boundary sediments was $23 \%$ for 13 elements (unpubl. data). If the clay boundaries in these sections do represent impact fallout because they are so homogeneous we should be able to calculate the amount of the various elements in the present work from the Ir content. But the abundances of $\mathrm{Fe}, \mathrm{Cs}$, $\mathrm{Cr}, \mathrm{Hf}, \mathrm{Ta}$, and $\mathrm{Co}$ in this work average 11 times the abundances (Alvarez et al., 1980) in the Stevns Klint section (when normalized to the same Ir content) and so would overwhelm any impact component such as deduced for Stevns Klint. If the clay in the Ir region were due to continental debris, then the ratio of $\mathrm{Fe}$ to $\mathrm{Cs}$ should remain constant. The $\mathrm{Fe} / \mathrm{Cs}$ ratio increases by a factor of 4 in the peak compared to the region below and decreases almost as much in the next $6 \mathrm{~cm}$ above.

Therefore, the clay in the region of the main Ir peak is not primarily due to impact fallout or normal continental deposition, 


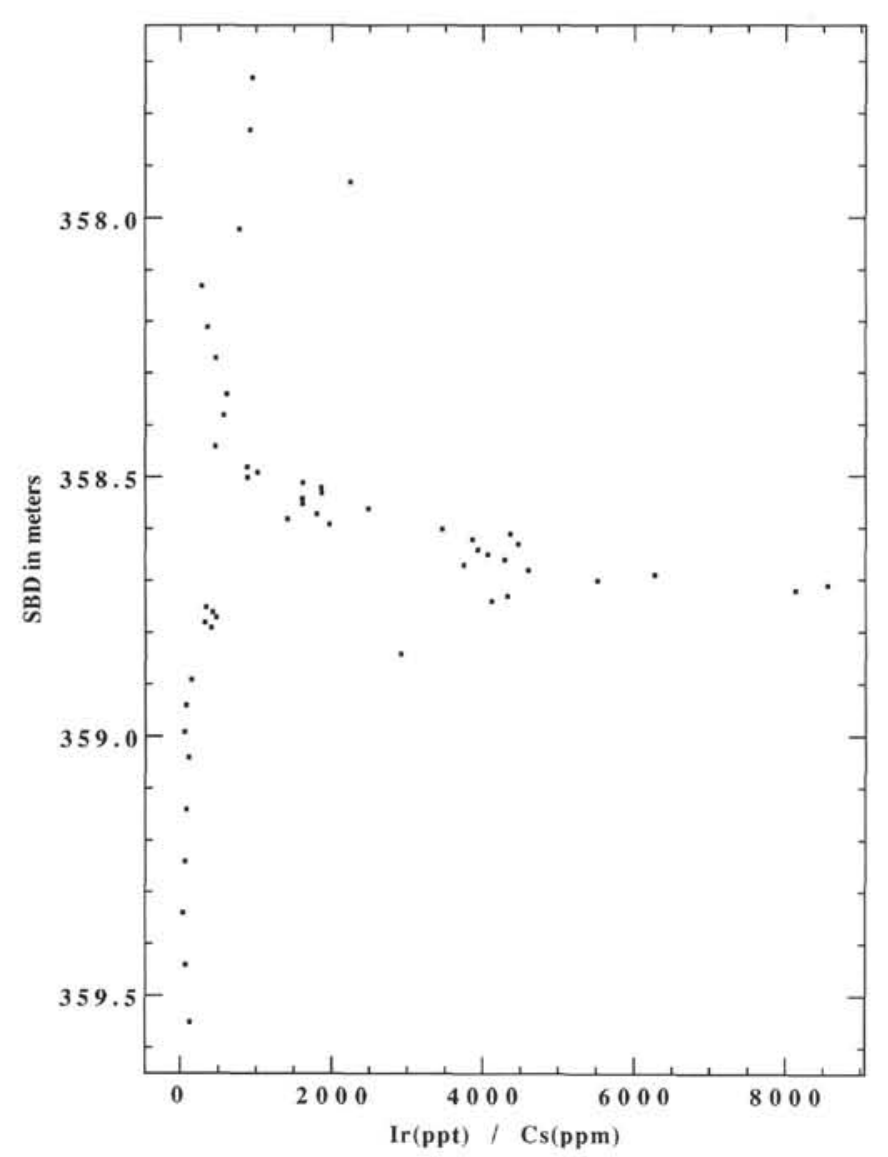

Figure 4. Detailed $\operatorname{Ir}(\mathrm{ppt}) / \mathrm{Cs}(\mathrm{ppm})$ abundance ratio profile vs. stratigraphic depth in region of Ir peaks.

but probably originated as a basaltic ash. As one proceeds upsection the $\mathrm{Fe} / \mathrm{Cs}$ ratio begins to rise above interval 121-752B-11R-3, $95 \mathrm{~cm}$, where there is a biscuit boundary and there appears to be a sharp increase in the element abundances including that of Ir. The peak of the ash (i.e., the peak in Fe) appears to be $1 \mathrm{~cm}$ higher than the Ir peak. As close as we can measure (within about 1 or 2 $\mathrm{cm}$ ), the beginning of the deposition of ash seems to have paralleled the beginning of the deposition of Ir.

As discussed in the Introduction, the authors believe the evidence from many sections around the world connecting the $\mathrm{K}-\mathrm{T}$ Ir anomaly with a bolide impact is convincing. In that event, the impact could have triggered a basaltic eruption or the two could have accidentally happened at the same time. The latter explanation may be unlikely because of the close correspondence between the $\mathrm{Fe}$ (indicating ash) and the Ir peaks. Also, the $\mathrm{Co} / \mathrm{Fe}$ ratios for nearly all samples studied in this work (including ash layers) are about 4 , with the notable exception of those in the region from interval 121-752B-11R, $71-95 \mathrm{~cm}$. At the lower bound of this region, the ratio increases precipitously by a factor of 3 , stays that high or higher throughout, and then just as precipitously decreases by a factor of 3 at the upper bound. This behavior might suggest the character of the basaltic volcanism changed at the time of the deposition of the Ir, i.e., a volcanic source was activated with larger $\mathrm{Co}$ content relative to $\mathrm{Fe}$ than the sources which produced the other ash layers studied in this work.

An alternative explanation for the $\mathrm{Co}$ is that the impact could have deposited a large mass of biological material on the ocean bottom which triggered a reducing environment with production of $\mathrm{H}_{2} \mathrm{~S}$, such as deduced for the Gubbio K-T boundary (Lowrie et al, 1990). This environment would have precipitated Co and $\mathrm{Ag}$

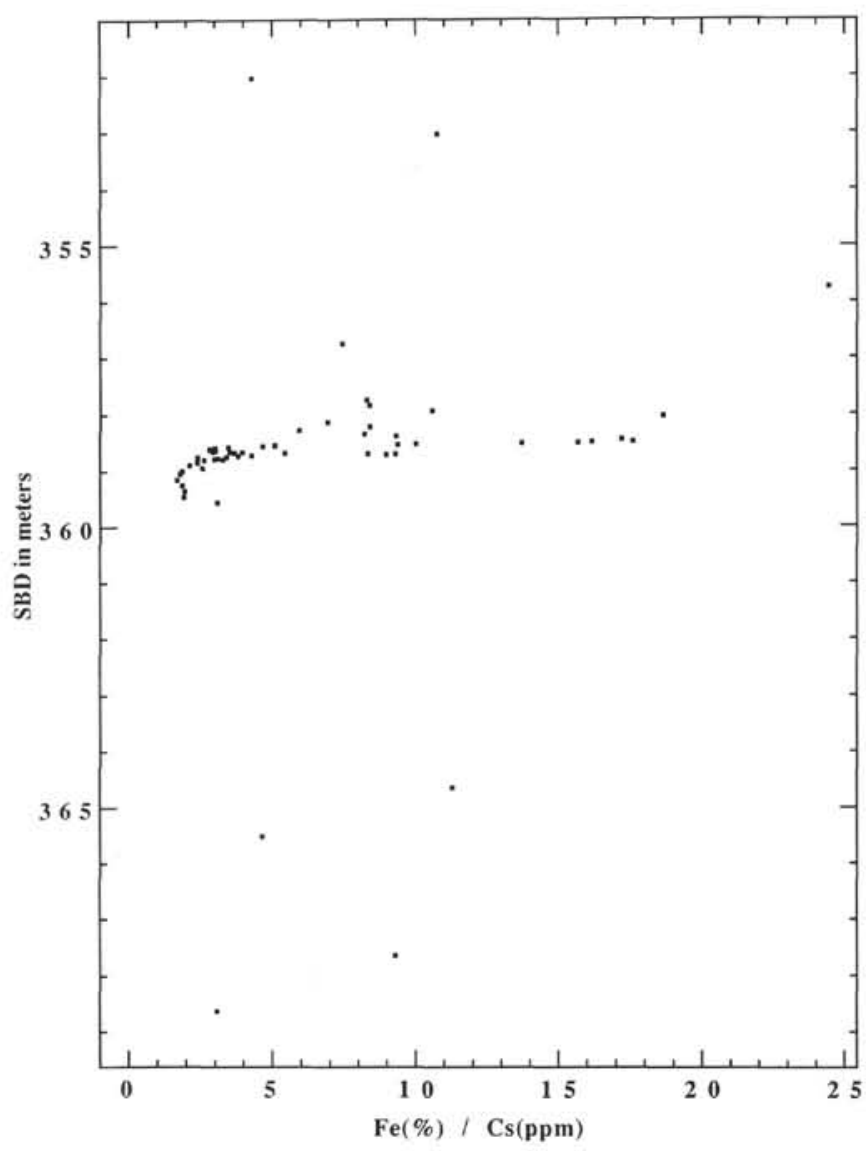

Figure $5 . \mathrm{Fe}(\%) / \mathrm{Cs}(\mathrm{ppm})$ abundance ratio profile vs. stratigraphic depth for all samples studied from Hole 752B.

from the seawater (Turekian, 1976) and may also have precipitated $\mathrm{Se}$, which is chemically similar to $\mathrm{S} . \mathrm{H}_{2} \mathrm{~S}$ could also have precipitated $\mathrm{Ni}, \mathrm{Cu}, \mathrm{Cd}, \mathrm{Hg}, \mathrm{Pb}$, and $\mathrm{Zn}$ (Turekian, 1976), but these were not measured. When the reducing environment disappeared, the enhancements of these insoluble sulfides would also disappear. Between Samples 121-752B-11R-3, 71-72 cm, and $70-71 \mathrm{~cm}$, where the $\mathrm{Co} / \mathrm{Fe}$ ratio is restored to its low value, $\mathrm{Se}$ dropped in abundance by a factor of 4.5 and Co dropped by a factor of 2.5. Crude measurements of $\mathrm{Ag}$ (not shown) showed its abundance also dropped about a factor of 4 . All other measured elements (excepting Ir and including the ones not listed) averaged only a $6.4 \%$ difference. Subsequent measurements of other elements expected to be deposited out of seawater in sulfide-rich environments could determine if this explanation is a viable one.

The sharp change in $\mathrm{Co}, \mathrm{Se}, \mathrm{Ag}$, and $\mathrm{Ir}$ at interval 121-752B$11 \mathrm{R}-3,71 \mathrm{~cm}$, may be illusory. Figure 1 shows a break in the core at interval $121-752 \mathrm{~B}-11 \mathrm{R}-3,72 \mathrm{~cm}$. The two positions may correspond and possibly a considerable amount of core might be missing directly above. The change in the Ir abundance could be due to this effect as the Ir/Cs ratio changes precipitously at this point.

\section{Overall Relative Productivity (Calcareous + Siliceous)}

In the calculations of the ratios of overall productivity from the chemical abundance data, we assume that over the region from 359.44 to $358.54 \mathrm{~m}$ sub-bottom depth there is a rough constancy in the deposition rate of clay from the continents, in the Cs abundance of the continental clay, and in the density of the rock. The calculations are insensitive to the actual values of the above parameters and the changes in Cs abundance of the basalt during 


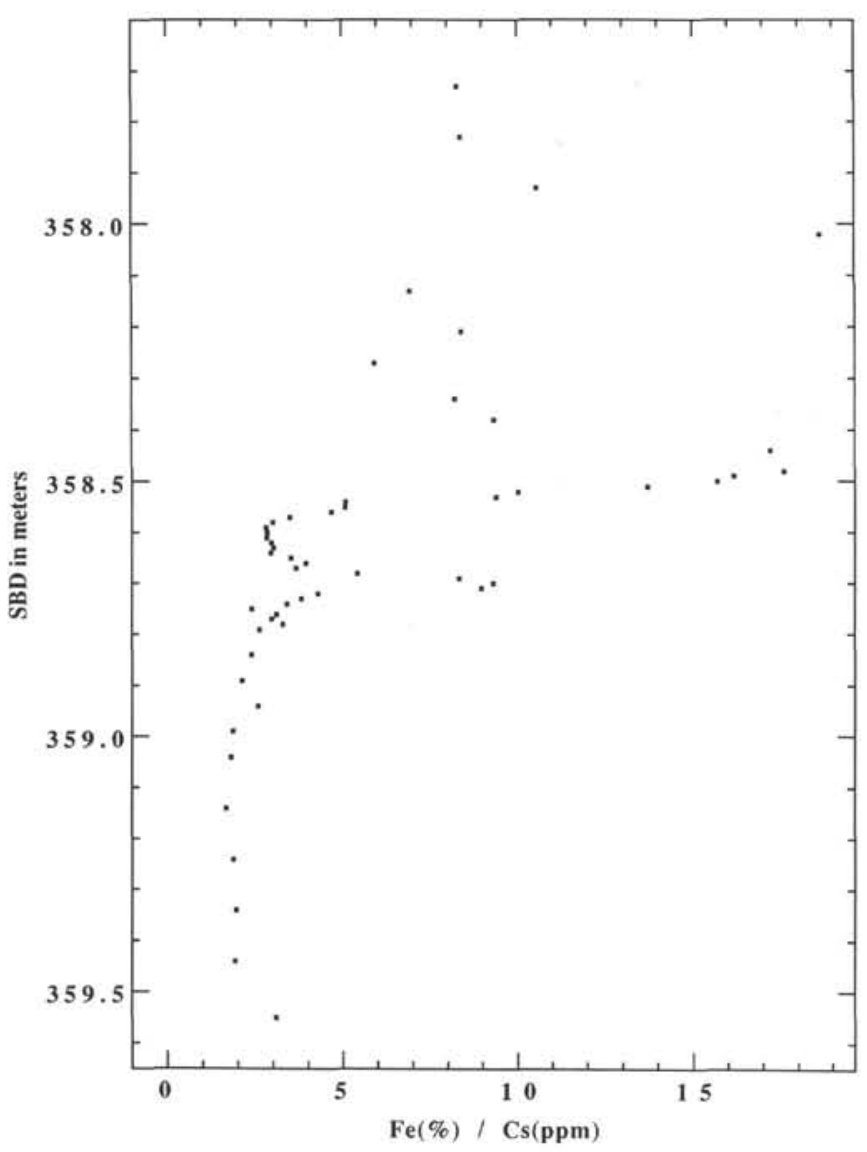

Figure 6. Detailed $\mathrm{Fe}(\%) / \mathrm{Cs}(\mathrm{ppm})$ abundance ratio profile vs. stratigraphic depth in region of Ir peaks.

its diagenesis. The calculations assume the sediments below the Ir-rich region with very low $\mathrm{Fe}$ abundance do not contain significant amounts of altered basalt. They also assume that enhanced iron abundances in the sediments in the Ir-rich region are due to altered basalts which contain $\mathrm{Fe}$ in the same abundance as found in altered basalts in other parts of the section.

The Cs content in the K-T clay layer is about twice the value found in the Cretaceous sediments from interval 121-752B-11R$3,109 \mathrm{~cm}$, to interval $121-752 \mathrm{~B}-11 \mathrm{R}-4,26 \mathrm{~cm}$. If we use the average $\mathrm{Fe}$ abundance of six basalts from Hole 754B reported by the Shipboard Scientific Party, 10\%, the altered basalt component in our K-T boundary sample with highest $\mathrm{Fe}$ (and $\mathrm{Cs}$ ) at interval $121-752 \mathrm{~B}-11 \mathrm{R}-3,90-91 \mathrm{~cm}$, is $40 \%$. If we exclude the altered basalt component, the maximum $\mathrm{Cs}$ abundance is then 3.4 times the background sediment value. This places a lower limit on the productivity of about one-third the latest Maestrichtian rate about $1 \mathrm{~cm}$ above the position of most abundant Ir. The overall productivity recovers rapidly (within $3 \mathrm{~cm}$ of the position of the most abundant Ir) and then increases until it is about 5 times the latest Maestrichtian rate at interval $121-752 \mathrm{~B}-11 \mathrm{R}-3,77-80 \mathrm{~cm}$, i.e., the Cs abundance is about 5 times lower than the latest Maestrichtian value. Instead of $\mathrm{Cs}$ we could have used $\mathrm{Fe}, \mathrm{Hf}$, or Ta and obtained qualitatively similar results about the productivity recovery. The region in Section 121-752B-11R-3 between 76 and $84 \mathrm{~cm}$ was described (Shipboard Scientific Party, 1988a) as being pebbles of gray chert and porcellanite. Therefore, the enhanced productivity was probably due to siliceous rather than calcareous organisms.

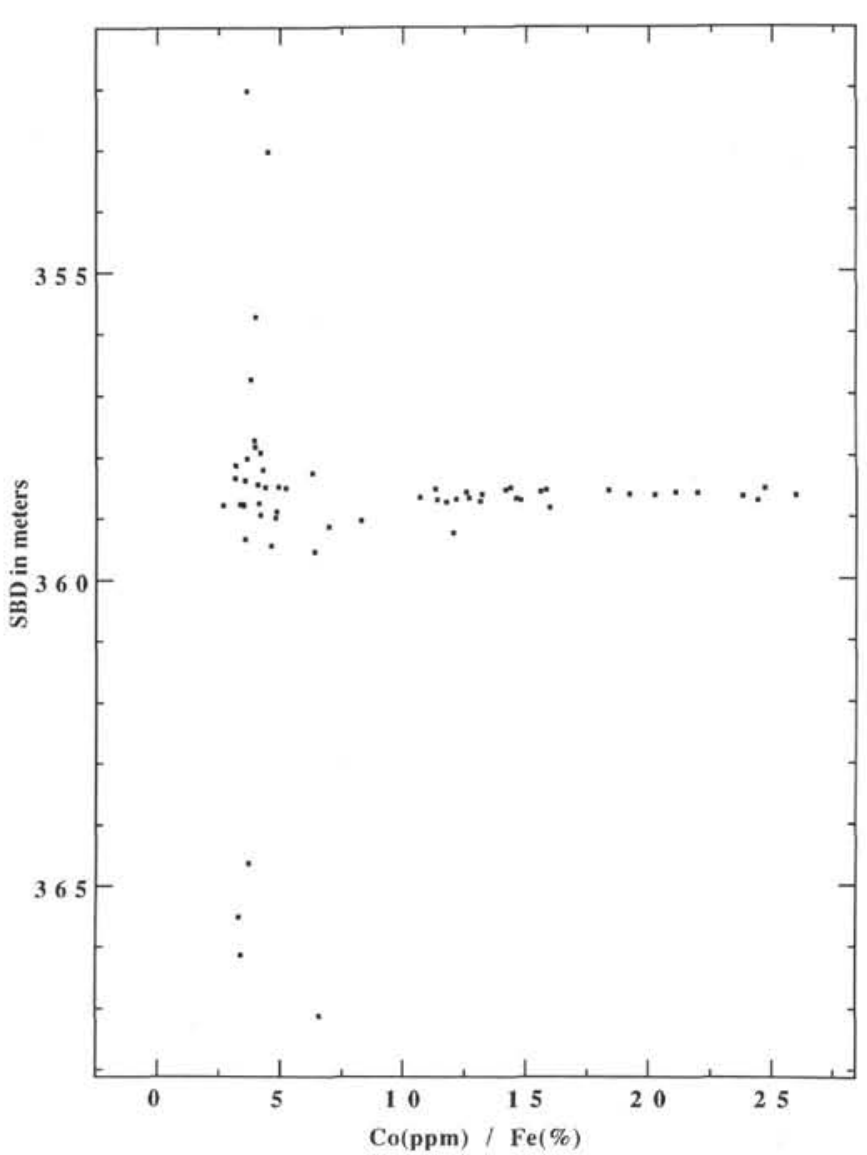

Figure 7. $\mathrm{Fe}(\%) / \mathrm{Co}(\mathrm{ppm})$ abundance ratio profile vs. stratigraphic depth for all samples studied from Hole 752B.

\section{Other Iridium Peaks}

The ratios of $\mathrm{Ir}$ to $\mathrm{Cs}$ in the units given in Table I have a best value of $70 \pm 7$ for the samples more than $12 \mathrm{~cm}$ below the main Ir peak background region described above. Not until Sample 121-752B-10R-5, 93-94 cm, which is $7 \mathrm{~m}$ higher, does the $\mathrm{Ir} / \mathrm{Cs}$ ratio come down to this background level again.

Figure 2 shows an Ir peak of $1500 \mathrm{ppt}$ at interval 121-752B$11 \mathrm{R}-3,13-14 \mathrm{~cm}$, with tails extending at least $20 \mathrm{~cm}$ above and below. This peak is $1 \mathrm{~cm}$ away from the position where the Shipboard Scientific Party (1988a) reported an abundant recurrence of Cretaceous nannofossils which they ascribed to reworking. By analogy the Ir peak is ascribed to reworking of K-T boundary sediments from another location.

Twelve $\mathrm{cm}$ below the main peak there is a peak with $862 \mathrm{ppt}$ Ir. The ratios of measured elements in this position are similar to those of the K-T boundary clay, but no admixture of the boundary and the other sediments would give exactly the observed abundance. The Ir and other elements may be enhanced because of bioturbation of the K-T boundary clay. Alternatively, if the samples from intervals 121-752B-11R-3, 104-105 cm, and 121$752 \mathrm{~B}-11 \mathrm{R}-3,95-96 \mathrm{~cm}$, had somehow been interchanged in the sample preparation or sampling process, most of the element abundance profiles would be smoother, but that of Se would be double-peaked.

There is Ir above background levels from $17 \mathrm{~cm}$ below to at least $1 \mathrm{~m}$ above the main Ir peak. The three samples from between 
2.0 and $5.7 \mathrm{~m}$ above that peak average about $59 \mathrm{ppt}$ Ir and probably contain altered volcanic basalts. The main Ir peak has tails both upsection and downsection, but the latter is an order of magnitude more abundant than the latter. Marine K-T boundaries characteristically have tails of Ir extending into the Tertiary sediment and to a lesser extent into the Cretaceous sediment. The former may be due to transport of Ir from other areas and the latter may be due to diffusion or bioturbation.

\section{ACKNOWLEDGMENTS}

This work was supported by the Director, Office of Energy Research, office of Basic Energy Sciences, Chemical Sciences division of the U.S. Department of Energy under contract No. DE-AC03-76SF00098. We also thank the National Aeronautics and Space Administration for their support under contract No. A-59508C. The construction and modification costs of the Iridium Coincidence Spectrometer were borne principally by the Murdoch Charitable Trust.

The neutron irradiations were most capably provided by the staff of the University of Missouri Triga reactor. We are indebted to Kristine Ing for preparation of the samples and plotting of the graphs and to Linda Sindelar for coordinating the sample packaging and shipping. The staff of the Ocean Drilling Program has been particularly helpful to us in providing not only the samples but also documentation which assisted in the evaluation of the work. We are indebted to the National Science Foundation whose funding makes the deep-sea drilling programs possible.

\section{REFERENCES}

Alvarez, L. W., Alvarez, W., Asaro, F., and Michel, H. V., 1980. Extraterrestrial cause for the Cretaceous-Tertiary extinction. Science, 208:1095-1108.

Alvarez, L. W., Asaro, F., Goulding, F. S., Landis, D. A., Madden, N. W., and Malone, D. F., 1988. Instrumental measurement of iridium abundances in the part-per-trillion range following neutron activation. Abstr. 196th ACS Nat. Meeting. Am. Chem. Soc., NUCL-30.

Alvarez, W., and Asaro, F., 1990. What caused the mass extinction? an extraterrestrial impact. Sci. Am., 263:76-84.

Alvarez, W., Asaro, F., Alvarez, L. W., and Michel, H. V., 1990. The debate over the Cretaceous-Tertiary Boundary. Proc. Conf. Global Catastrophes in Earth History. Snowbird, Utah, Oct. 20-23, 1988. (Abstract)

Alvarez, W., Asaro, F., Michel, H. V., and Alvarez, L. W., 1982. Iridium anomaly approximately synchronous with terminal Eocene extinctions. Science, 216:886-888.

Alvarez, W., Asaro, F., and Montanari, A., 1990. Ir profile for 10 million years across the Cretaceous-Tertiary boundary at Gubbio, Italy. Science, 250:1700-1702.

Asaro, F., Alvarez, L. W., Alvarez, W., and Michel, H. V., 1987. Operation of the iridium coincidence spectrometer. Studies in the middle Miocene and near the Cenomanian-Turonian Boundary. Abstr. of IGCP 199, Rare Events in Geol. Conf., Beijing, Peoples Rep. of China, 65.

Basaltic Volcanism Study Project, 1981. Basaltic Volcanism on the Terrestrial Planets: New York (Pergamon Press).

Bohor, B. F., Foord, E. E., Modreski, P. J., and Triplehorn, D. M., 1984. Mineralogical evidence for an impact event at the Cretaceous-Tertiary boundary. Science, 244:867-869.
Courtillot, V. E., 1990. What caused the mass extinction? A volcanic eruption. Sci. Am., 263:85-92.

Elliott, W. C., Aronson, J. L., Millard, Jr., H. T., and Gierlowski-Kordesch, E., 1989. The origin of the clay minerals at the Cretaceous/Tertiary boundary in Denmark. Geol. Soc. Am. Bull., 101:702-710.

Ganapathy, R., 1980. A major meteorite impact on the earth 65 million years ago: evidence from the Cretaceous-Tertiary boundary clay. Science, 209:921-923.

Hallam, A., 1987. The end-Cretaceous mass extinction event: argument for terrestrial cause. Science, 238:1237-1242.

Izett, G. A., 1988. The Cretaceous-Tertiary (K-T) boundary Interval, Raton Basin, Colorado and New Mexico, and its content of shockmetamorphosed minerals: implications concerning the K-T boundary impact-extinction theory. Open-File Rep. U.S. Geol. Surv., No. 87 606.

Johnsson, M. J., and Reynolds, R. C., 1986. Clay mineralogy of shalelimestone rhythmites in the Scaglia Rossa (Turonian-Eocene), Italian Apennines. J. Sediment. Petrol., 56:501-509.

Kastner, M., 1982. Reported by F. Asaro in Proceedings of the K-TEC II Workshop, Syllogeus, 39:31.

Kastner, M., Asaro, F., Michel, H. V., Alvarez, W., and Alvarez, L. W., 1984. The precursor of the Cretaceous-Tertiary boundary clays at Stevns Klint, Denmark, and DSDP Hole 465A. Science, 226:137-143.

Kerr, R. A., 1988. Huge impact is favored K-T boundary killer. Science, 242:865-867.

Kyte, F. T., and Wasson, J. T., 1986. Accretion rate of extraterrestrial matter: iridium deposited 33 to 67 million years ago. Science, 232:1225-1229.

Lowrie, W., Alvarez, W., and Asaro, F., 1990. The origin of the White Beds below the Cretaceous-Tertiary boundary in the Gubbio section, Italy. Earth Planet. Sci. Lett., 98:303-312.

Michel, H. V., Asaro, F., Alvarez, W., and Alvarez, L. W., 1990. Geochemical studies of the Cretaceous-Tertiary boundary in ODP Holes 689B and 690C. In Barker, P. F., Kennett, J. P., et al., Proc. ODP, Sci. Results, 113: College Station, TX (Ocean Drilling Program), 159168.

Nazarov, M. A., Badjukov, D. D., Barsukova, L. D., and Alekseev, A. S., 1987. Cretaceous/Tertiary event: geochemistry of Turkmenia $\mathrm{K} / \mathrm{T}$ sections. LPSC, 18:700-701.

Officer, C. B., Hallam, A., Drake, C. L., and Devine, J. D., 1987. Late Cretaceous and paroxysmal Cretaceous/Tertiary extinctions. Nature, 326:143-149.

Perlman, I., and Asaro, F., 1969. Pottery analysis by neutron activation. Archaeometry, 11:21-52.

1971. Pottery analysis by neutron activation. In Brill, R. H. (Ed.), Science and Archaeology: Cambridge, MA (MIT Press), 182195.

Rampino, M. R., and Reynolds, R. C., 1983. Clay mineralogy of the Cretaceous-Tertiary boundary clay. Science, 219:495-498.

Schmitz, B., 1988. Origin of microlayering in worldwide distributed Ir-rich marine Cretaceous/Tertiary boundary clays. Geology, 16:1068-1072.

Shipboard Scientific Party, 1989a. Cretaceous/Tertiary boundary summary. In Peirce, J., Weissel,J., Proc. ODP, Init. Repts., 121: College Station, TX (Ocean Drilling Program), 507-516.

1989b. Broken Ridge summary. In Peirce, J., Weissel, J., Proc. $O D P$, Init. Repts., 121: College Station, TX (Ocean Drilling Program), 457-506.

Turekian, K. K., 1976. Oceans: Englewood Cliffs, NJ (Prentice Hall).

Date of initial receipt: 7 March 90

Date of acceptance: 23 October 1990

Ms 121B-177 